UDC 504.453

Lesya O. Vasilenko, $\mathrm{PhD}$, Associate Professor of the Department of Occupational Safety and Environment

ORCID ID 0000-0003-0450-8330 e-mail: lesya.kiev@ukr.net

Olena G. Zhukova, PhD, Associate Professor of the Department of Occupational Safety and Environment

ORCID ID 0000-0003-0662-9996 e-mail: elenazykova21@gmail.com

Angelina A. Kokitko, student

ORCID ID 0000-0002-4225-1268

Kyiv National University of Construction and Architecture, Kyiv, Ukraine

\title{
ESTIMATION AND FORECAST OF CHANGES IN THE HYDROCHEMICAL STATUS OF THE TISZA RIVER
}

\begin{abstract}
The engineer-ecological indexes and their parameters are used at the ecological estimation of the status of hydroecosystems (HE) of the Tisza water basin. The system-basin approach of research of the water basin bazed on the systematization and processing of environmental monitoring data for the long-term period was used. Such period allowed to set scientific conformities of the development of naturally-anthropogenic hydroecosystems in the conditions of constant technogenic load on them.

Keywords: water system; biotic communication; hydroecosystem
\end{abstract}

\section{Introduction}

On the modern stage of development of industry and national economy the problem of rational nature management becames extraordinarily actual. Foremost it is related to constantly growing anthropogenic influence of man on an environment. As known, the rivers are most sources of fresh waters for an economy and industry, at the same time, by points for the upcast of industrial wastes and effluents, that results not only in quality but also quantitative exhaustion. Therefore the decision of problem of maintenance and proceeding in the self-potential of water basins becomes especially actual and ecological.

The Tisza river is the most inflow of Danube, the area of water mirror of that presents 157186 kilometres $^{2}$. Length of the Tisza river makes a $966 \mathrm{~km}$. Basic part of Tisza flow is formed on territory four held: to Romania $-51 \%$, Ukraine $-25,6 \%$, Hungary $-10 \%$, Slovakia $-13,4 \%[1,2]$.

Ukrainian part of the Tisza basin the belongs both to Overhead Tisza and Middle Tisza. The basin of the Tisza river is the basic source of water-supply of the Zakarpattia area. The total resources of superficial flow in a medieval year make 13300 million $\mathrm{m}^{3}$, in shallow is 7290 million $\mathrm{m}^{3}$. Except waters Tisza, 9 storage basins (a general capacity is 59,3 million $\mathrm{m}^{3}$ ), 286 ponds (a general capacity is 10,056 million $\mathrm{m}^{3}$ ) and 32 lakes among that most is, enter to them. Synevir by volume of 1,75 million $\mathrm{m}^{3}[3]$.

The level of water consumption of area is insignificant. In 2016 all from natural sources 42,67 million $\mathrm{m}^{3}$ of water is taken away, among them 43 surface-water and 
57 underground. On territory to the area water-intensive productions that need the far of water are absent [4]. The prognosis resources of underwaters of drinkable quality make 399 million $\mathrm{m}^{3} /$ year, and the level of ratified presents 124 million $\mathrm{m}^{3} /$ year. By the state on 2016 used all only about 18,85 million $\mathrm{m}^{3} /$ year, id est, an area has considerable potential for development of drinkable water-supply. Relative part of collection of waters Tisza presented on fig. 1.

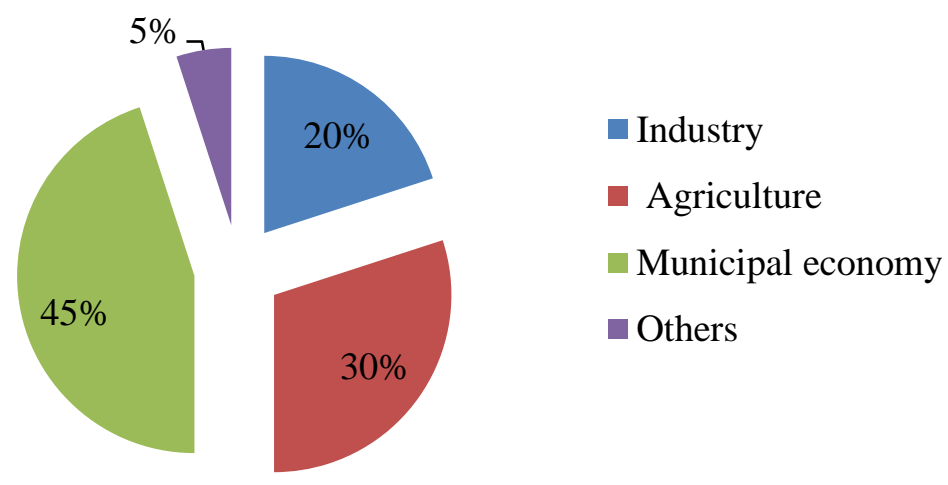

Fig. 1 - The structure of water use of the Tisza river

For period 1990-2016 tendency to considerable reduction of volumes to the water intake of water that takes place mainly due to reduction of the use on to trade and agricultural necessities was observed.

\section{Main part}

Prognosis of water consumption of waters Tisza is determined by the rates of economic and public development. According to calculations of scientists 2031 to amount of population in the district of water basin of the Tisza will increase more than in 5 times, as a result the increase of closeness of population will take place from 97,5 to 102,2 persons/of $\mathrm{km}^{2}$. The calculation water consumption of area can be fully provided due to local water resources, for what the conducted measures must be from maintenance and proceeding in present water resources. In obedience to calculations the structure of fence lead will have such kind - fig. 2.

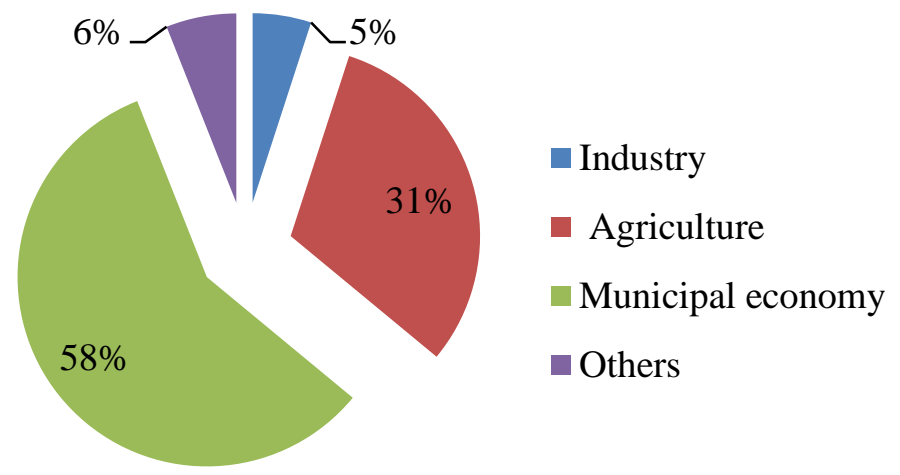

Fig. 2 - The prognosis of structure of water use of the Tisza river 
Contaminants come to the Tisza basin through the natural and anthropogenic sources of contamination. Basic sources of contamination of surface-water of river of Yew basin organic substances: communal sewer water; industry; agriculture [5].

In the picture 3 the diagram of distribution of volume of effluents between industries is presented.

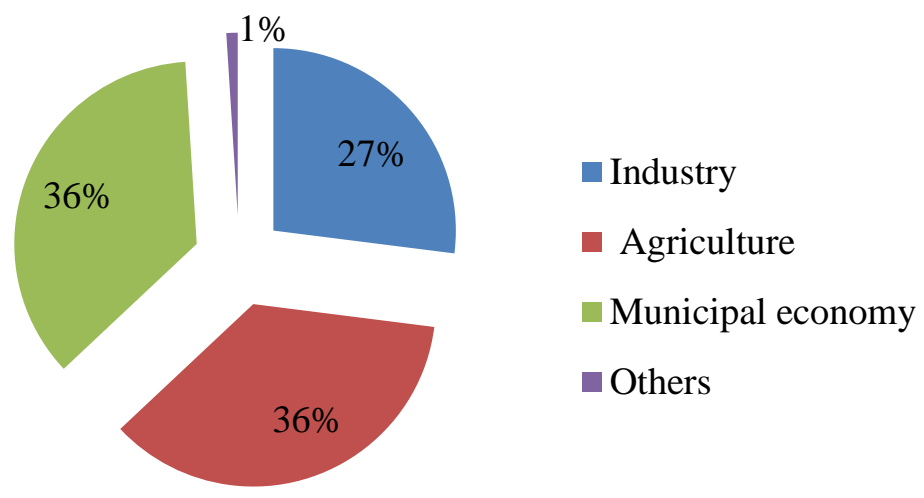

Fig. 3 - A diagram of distribution of volume of effluents is between industries in 2016 year

For the last two decades, a political and economic situation caused changes in industrial activity that comes true in Zakarpattia. From data of the state statistical accounting about the use of waters, common amount of water users that carry out the upcast of effluents in the superficial water objects of the Tisza basin in 2016 made 106 subjects, in next sectors: industry is 35 subjects, including electroenergy -2 ; standard -1 ; chemical and petrochemical -1 ; machine-building and metal-working -4 ; woodworking -5 ; forest-chemical -1 ; building -5 ; light industry -1 ; food industry -15 ; agriculture -8 ; forestry -1 ; transport -3 ; building -1 ; trade -2 ; logistical support -3 ; housing and communal services -53 [6].

Contamination organic substances from the effluents of industry is insignificant. All in 2016 year by them it was downfaulted: organic substances -0.01 thousand tons (according to the Biochemical Oxygen Consumption full $_{\text {) }}, 0.017$ thousand tons (for Chemical consumption of oxygen $\mathrm{Cr}_{\mathrm{r}}$ ).

The estimations of quality of water carried out from data of monitoring 2013-2016. The Primary purpose of research is an estimation ecological state of the Tisza river on physical and chemical indexes, exposure of basic sources of anthropogenic influence and determination of directions of improvement of the state of water object.

For calculations the base of statistical data of the ecological monitoring was created. All in a database contained information about more than a 200 water meters for hydrochemical descriptions.

In the tests of waters content is certain for to the indexes: $\mathrm{pH}$, Biochemical Oxygen Consumption, 5 , self-weighted substances, taste, iron a common, potassium, calcium, magnesium, manganese, copper, natrium, oil products, Chemical consumption of oxygen, cut-in oxygen, surface active substances, sulfates, phenols, phosphates, chrome(VI), percent of oxygenating, hydrocarbonates, resins and pyrobitumens, nitrogen ammoniacal, nitrogen a nitrite, nitrogen nitrate, silicon, zinc, pesticides $\alpha$-Hexachloran, pesticides $\gamma$-Hexachloran, pesticides of $p$, 


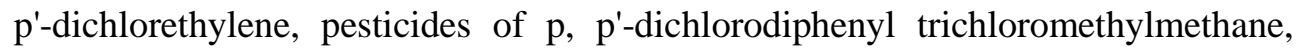
pesticides of $\mathrm{p}, \mathrm{p}^{\prime}$-dichlorodiphenyl dichloroethane, and also coloured, smell, expense of water of the river, speed of flow, temperature of water.

Analyzing results on the whole, it should be noted that content of such substances as oil products, ions of copper and zinc, surface-active substances, nitrogen ammoniacal, nitrogen a nitrite, nitrogen is nitrate and a chrome general remains stable during the period of research.

A concentration of hydrogen is one of major indexes of quality of waters, that influences on the chemical equilibrium of ions in the system and matters very much for chemical and biological processes. Its amount in the Tisza river changes from 7,6 to 8,1 od. $\mathrm{pH}$.

The amount of hydrocarbonates and chlorides in water presents $128-152$ and $10-17 \mathrm{mg} / \mathrm{dm}^{3}$ accordingly. Content of chlorides is considerably below from HDC $\left(350 \mathrm{mg} / \mathrm{dm}^{3}\right)$ and testifies that salt contamination by this anion in water it is not. The amount of sulfates hesitates a from 23 to $30 \mathrm{mg} / \mathrm{dm}^{3}$, that considerably below from HDC $\left(100 \mathrm{mg} / \mathrm{dm}^{3}\right)$. Reduction to the concentration of hydrocarbonates and sulfates is educed also on stream of the river.

Content of calcium and magnesium in river waters during the investigated period was within the limits of $36-41 ; 6,5-7,3 \mathrm{mg} / \mathrm{dm}^{3}$ accordingly and does not exceed their HDC $\left(180,40 \mathrm{mg} / \mathrm{dm}^{3}\right.$ accordingly). In all tests of amount of calcium substantially prevail content of magnesium. There is a tendency to reduction of concentrations to the calcium down stream.

Middle-aged of concentration to the ammonium salt in waters did not exceed HDC $\left(0,5 \mathrm{mg} / \mathrm{dm}^{3}\right)$. The concentrations of nitrites in water presented $0,02-0,08 \mathrm{mg} / \mathrm{dm}^{3}$, and content of nitrates is within the limits of a $1,1-6,5 \mathrm{mg} / \mathrm{dm}^{3}$, that does not exceed HDC ( 0,08 and $40 \mathrm{mg} / \mathrm{dm}^{3}$ accordingly).

In obedience to calculations mean values of index of contamination of salt composition $\left(I_{1}\right)$ - 1,57; tropho-saprobiological (ecological and sanitary) index $\left(I_{2}\right)-$ 3,12 ; index of specific indexes of toxic action $\left(I_{3}\right)-4,02$; ecological index $\left(I_{\mathrm{e}}\right)-2,94$.

Data of prognoses are erected in a table 1. Reliability of prognosis is appraised on the basis of level of meaningfulness of $p$ : than less level of meaningfulness, the greater reliability of prognosis. Consider a prognosis reliable enough, in what $p \leq 0,05$. Obviously, that prognoses of content to the ammonium and iron is only an orientation, as them $p>0,05$. All other the prognoses it follows to consider reliable enough.

Prognostication of content of pollutants gives an opportunity not only to envisage a concentration but also estimate the general tendency of seasonal change of substance.

Table 1 - Data of prognosis and reliability of prognosis

\begin{tabular}{|c|c|c|}
\hline Index, $\mathrm{mg} / \mathrm{dm}^{3}$ & Forecast, $\mathrm{mg} / \mathrm{dm}^{3}$ & Level of significance \\
\hline Nitrogen is ammoniacal & 0,12 & 0,48 \\
\hline Chemical consumption of oxygen & 6,1 & 0,004 \\
\hline Biochemical Oxygen Consumption ${ }_{5}$ & 3,1 & 0,02 \\
\hline General phosphorus & 0,13 & 0,007 \\
\hline
\end{tabular}

For the prognosis of the state of the Tisza water system by us those indexes that limit and most suitable for prognostication a statistical method was select: Chemical consumption of oxygen, nitrogen ammoniacal, phenols, phosphorus general, oil products, surface active substances, Biochemical Oxygen Consumption 5 . For select 
indexes there were the expected parameters but also b, what necessary for corresponding equalizations regressions. However, for prognostication of the state hydroecosystems can be used only those equalizations, at what copulas between signs very close (value of coefficient of correlation of $r$ nearer to 1 ) and if calculation value of $t$ exceeds a tabular value (it testifies to substantial connection between a concentration and sometimes a criterion).

After determination of force of connection between a concentration and sometimes, appeared, that for a prognosis it is possible to use very small part of data. Most suitable for prognostication a statistical method average annual data are for Chemical consumption of oxygen, Biochemical Oxygen Consumption 5 , phosphorus is general and to nitrogen ammoniacal.

The actual task of water control is introduction of extra cleaning of domestic effluents after a bioscrubbing. Hereupon contamination of waters will be warned and the state of water objects will become better, and also the recreational value of region will rise.

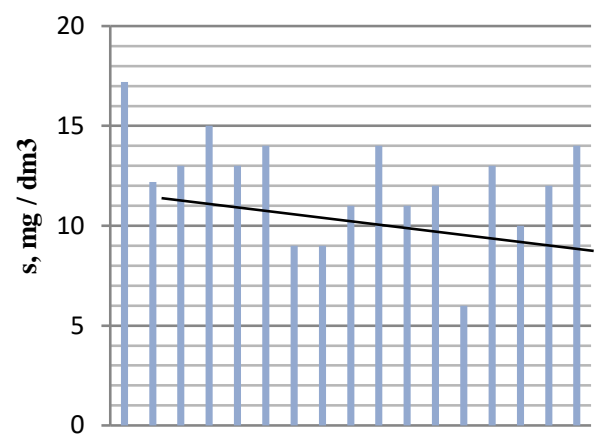

Fig. 4 - Prognostication of content of the ammonium ions

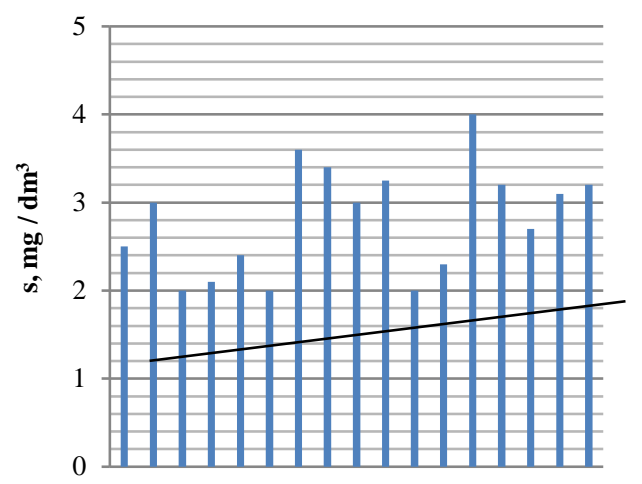

Fig. 6 - Prognostication of Biochemical Oxygen Consumption $_{5}$

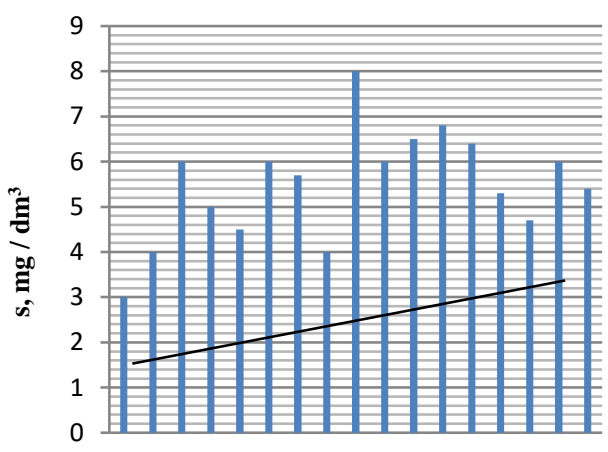

Fig. 5 - Prognostication of Chemical consumption of oxygen

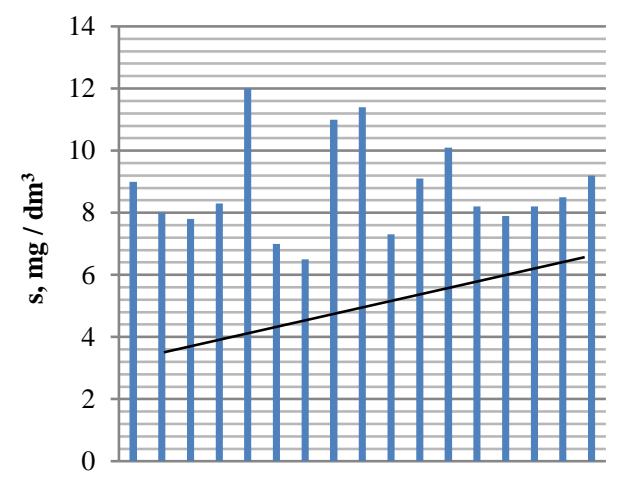

Fig. 7 - Prognostication of concentration of general phosphorus

According to figures 4-7 basic three indexes of Chemical consumption of oxygen, Biochemical Oxygen Consumption 5 and concentration of general phosphorus has a tendency to the increase, and indexes of ammonium ions - to the reduction.

\section{Conclusions}

By the basic sources of receipt of ions in water objects there are stock-raising farms an ammonium, service-utility sewer water, superficial flow from farmlands at the 
use of ammoniacal fertilizers, sewer water of enterprises of food, coke-chemical, wood-chemical and chemical industry.

Increase concentration of ammonium and phosphate ions used as an indicatory index of process of contamination of superficial and underground waters by domestic and agricultural flows.

\section{REFERENCES}

1. Marinich, O. M. (Ed.). (1989). Geographic Encyclopedia of Ukraine: In 3 volumes (Vol. 2). Kyiv: "Ukrainian Soviet Encyclopedia" by them. M.P. Bazhana (in Ukrainian).

2. Pop, S. S. (2003). Natural Resources of Transcarpathia: Teach. pos (2nd ed.). Uzhhorod: Spectral (in Ukrainian).

3. Gerenchuk, K. I. (Ed.). (1981). Nature of the Transcarpathian region. Lviv: Higher school (in Ukrainian).

4. Zastavecka, O. V., Zastaveckyi, B. I., Didchuk, I. I., \& Weaver, D. V. (1996). Geography of Transcarpathian region: textbook. Ternopil (in Ukrainian).

5. Rudenko, V. P. (1994). Natural Resource Potential of Ukraine. Kyiv: Lybid (in Ukrainian).

6. Transcarpathian Regional Water Authority. (2007). Water Fund of the Transcarpathian Region (surface water) [reference edition]. Uzhgorod: State Committee for Water Supply of Ukraine (in Ukrainian).

Text of the article was accepted by Editorial Team 30.07.2018

Л.О. Василенко, О.Г. Жукова, А.А. Кокітко

ОЦІНКА ТА ПРОГНОЗ ЗМІН ГІДРОХІМІЧНОГО СТАНУ р. ТИСА

Анотація. При екологічній оцінці стану гідроекосистем (ГЕ) водного басейну р. Тиса використовують інженерно-екологічні показники та їх параметри. Використано системно-басейновий підхід досліджень водного басейну, основою якого стала систематизація і обробка даних екологічного моніторингу за довгостроковий період. Такий період дозволив встановити наукові закономірності розвитку природноантропогенних гідроекосистем в умовах постійного техногенного навантаження на них.

Ключові слова: водна система; біотичні зв'язки; гідроекосистеми

\section{Василенко Леся Олексіївна}

кандидат технічних наук, доцент кафедри охорони праці і навколишнього середовища Київського національного університету будівництва і архітектури

Адреса робоча: 03037, Україна, м. Київ, проспект Повітрофлотський, 31

Тел.: +380935432684e-mail: lesya.kiev@ukr.net

ORCID ID 0000-0003-0450-8330

\section{Жукова Олена Григорівна}

кандидат технічних наук, доцент кафедри охорони праці і навколишнього середовища Київського національного університету будівництва і архітектури

Адреса робоча: 03037, Україна, м. Київ, проспект Повітрофлотський, 31

Тел.: +380968752104 e-mail: elenazykova21@ gmail.com

ORCID ID 0000-0003-0662-9996

\section{Кокітко Ангеліна Андріївна}

студентка 3-го курсу спеціальності 101 «Екологія» Київського національного університету будівництва і архітектури

Адреса робоча: 03037, Україна, м. Київ, проспект Повітрофлотський, 31

Тел.: +380962788049 e-mail: elenazykova21@ gmail.com

ORCID ID 0000-0002-4225-1268 